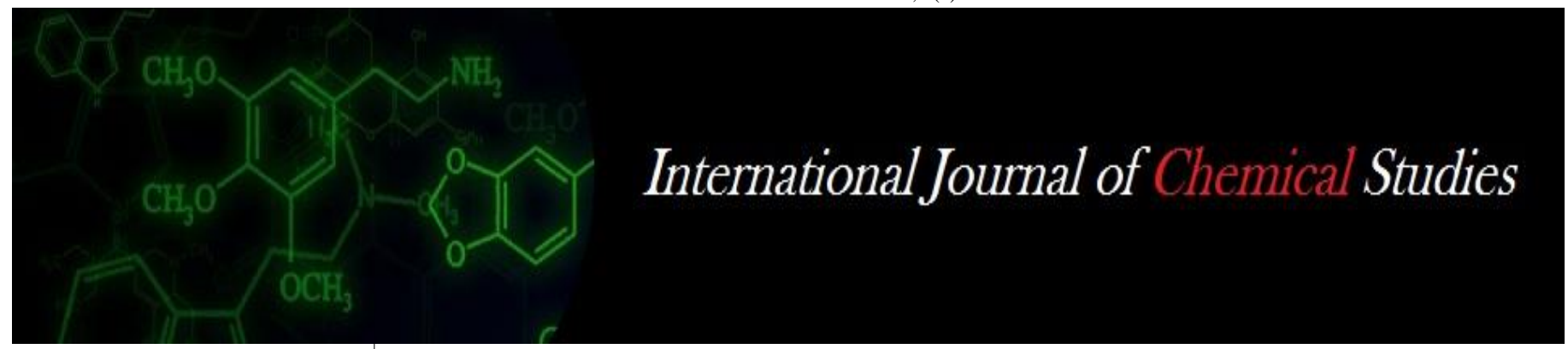

P-ISSN: 2349-8528

E-ISSN: 2321-4902

www.chemijournal.com

IJCS 2020; 8(2): 1638-1640

(C) 2020 IJCS

Received: 10-01-2020

Accepted: 14-02-2020

Neeraj Kumar Prajapati

Ph.D., Scholar, Department of

Extension Education, JNKVV,

Jabalpur, Madhya Pradesh,

India

VK Pyasi

Retd. Professor, Department of Extension Education, JNKVV, Jabalpur, Madhya Pradesh, India

Venkteshwar Jallaraph Senior Research Fellow, Department of Extension Education, JNKVV, Jabalpur, Madhya Pradesh, India

Corresponding Author: Neeraj Kumar Prajapati Ph.D., Scholar, Department of Extension Education, JNKVV, Jabalpur, Madhya Pradesh, India

\section{Aspiration of rural youth towards different agricultural activities}

\author{
Neeraj Kumar Prajapati, VK Pyasi and Venkteshwar Jallaraph
}

DOI: https://doi.org/10.22271/chemi.2020.v8.i2y.8994

\begin{abstract}
The present study was conducted purposively in Majhgawan block of Satna district to know the aspiration level of rural youth towards different agricultural activities. The Ex-Post Facto research design was used for the study. Multi stage sampling technique was employed to select the respondents. A sample of 80 rural youth was selected from 5 villages of Majhgawan block. The primary data were collected through personal interview method with the help of interview schedule which was prepared on the basis of objectives of investigation and variables. The data were analyzed with the help of statistical tools like- frequency, mean, percentage, mean score and statistical test viz. $\chi^{2}$ test and coefficient of association etc. The present study revealed that, majority of the rural youth had medium $(35.00 \%)$ level of aspiration towards different agricultural activities. In case of association education, caste, annual income, size of land holding, social participation, farming experience, innovativeness, extension participation, material possession, scientific orientation and risk orientation had significantly associated with the aspiration level of rural youth towards different agricultural activities.
\end{abstract}

Keywords: Aspiration, rural youth, coefficient of association

\section{Introduction}

Rural youth essentially form a vital human resource. Especially young person's between the age 15 to 30 will benefit from the policies programmes and projects that will emanate from the analysis and recommendations to increase the participation of rural youths in agriculture. The youth population in the country including adolescents is around 550 million (Census 2011). India had a total youth population of 460 million that is 40.00 per cent of the total population. Out of this population, about 70.00 per cent were rural youth. In addition the agricultural sector national economics and the region will also benefits as a consequence of the increase participation of youth. Increasing the participation of youths in agriculture could be an important means of improving food security, youth livelihoods and employment.

At present, the youth are having different needs, aspirations and values of life and accordingly they perform their activities and participation. The development of personal, social, economical and spiritual aspects of rural youth are possible, only when their needs, aspirations and their participation are recognized early and guided properly. Therefore, in this study some of these aspects were considered and which would be useful to the agencies involved in the development of rural youth. Aspirations literally mean 'hopes or ambitions to achieve something'. Aspirations also certainly have something to do with wants, preferences, choices, and calculations. They are multidimensional, many-faceted and socially embedded. They might either be complementary or may substitute each other, are usually formed through social interaction and differ from one society to another (Appadurai, 2004) ${ }^{[1]}$ we can said that it is youth orientation towards a particular social status like education, occupation, enterprises, income and so on. In present study aspiration refers to rural youths' orientation towards various enterprises in relation to various activities in agricultural and allied enterprise only.

\section{Material and Method}

The study was conducted purposively in Majhgawan block of Satna district due to ample scope and prospects of development for agricultural and allied activities due to progressive and diversified farming system. Only Majhgawan block was selected purposively due to office of 
K.V.K. The study was entirely concerned with rural youths who attended the vocational trainings organized by Krishi Vigyan Kendra situated at district Satna. In Majhgawan block, there are 188 villages. A list of villages was prepared with the help of RHEO/RAEO and local leaders and 5 villages were selected randomly. A list of the rural youths trainees was collected from K.V.K. personnel who were attended these training programme from each selected village. The trainees were categorized into different occupational aspects and only 16 rural youths trainees from each village have been selected through random sampling method for present study as respondents. Thus, there were total 80 respondents (youths) for this study. The primary data were collected through personal interview method with the help of interview schedule, which was prepared on the basis of objectives of investigation and variables. The statistical tests and procedures were used for analyzing the data with the help of statistical tools like- frequency, mean, percentage, mean score and statistical test viz. $\chi^{2}$ test and coefficient of association were used for analysis of data.

To know the enterprise aspiration in different agricultural activities of rural youth three point response continuum with perfect, partial and low with score of 3,2 and 1 respectively was used to quantify the enterprise aspiration in different agricultural activates of rural youth. Based on the total score obtained on each segment of enterprise they have been ranked, low, medium and high. On the basis of maximum and minimum score of the scale data were categorized into three categories as low, medium and high.

\section{Chi-square test}

The association between profile and aspiration of rural youth towards agricultural activities were analyzed by using Chi-
Square test $\left(\chi^{2}\right)$ formula.

$\chi^{2}=\sum \frac{(O i-E i)^{2}}{E i}$ With d.f. (r-1) (c-1)

Where,

$\mathrm{Oi}=$ Observed frequency

$\mathrm{Ei}=$ Expected frequency

$\sum=$ Summation over all differences

$\mathrm{r}=$ Number of rows

$\mathrm{c}=$ Number of column on the contingency table

\section{Co-efficient of association}

Extent of association was calculated by using Karl Pearson's formula for co-efficient of association (C)

$C=\sqrt{\frac{\chi^{2}}{\chi^{2}+N}}$

Where,

$\chi^{2}=$ Value of Chi-square

$\mathrm{N}=$ Number of observation

$\mathrm{C}=\mathrm{Co}$-efficient of association

\section{Results and discussion}

An aspiration refers to a person or a group of persons orientation towards a particular social status or status attribute like education, occupation, income and so on. In the present study aspirations refers to rural youth's orientation towards occupation in agriculture enterprise. 15 agro based enterprises were included in present study to know the aspirations of rural youth towards different agricultural activities.

Table 1: Distribution of rural youth according to their level of aspiration in different agricultural activities

\begin{tabular}{|c|c|c|c|c|c|c|c|}
\hline \multirow{2}{*}{ S.N. } & \multirow{2}{*}{ Area of aspiration } & \multicolumn{3}{|c|}{ Frequency } & \multirow{2}{*}{ Total score } & \multirow{2}{*}{ Mean } & \multirow{2}{*}{ Rank } \\
\hline & & Low interested & Medium interested & High interested & & & \\
\hline 1. & Crop production & $\begin{array}{c}25 \\
(31.25 \%)\end{array}$ & $\begin{array}{c}28 \\
(35.00 \%)\end{array}$ & $\begin{array}{c}27 \\
(33.75 \%)\end{array}$ & 162 & $2.02 *$ & $6^{\text {th }}$ \\
\hline 2. & Fruit production & $\begin{array}{c}21 \\
(26.25 \%)\end{array}$ & $\begin{array}{c}36 \\
(45.00 \%)\end{array}$ & $\begin{array}{c}23 \\
(28.75 \%)\end{array}$ & 162 & $2.02 *$ & $7^{\text {th }}$ \\
\hline 3. & Vegetable production & $\begin{array}{c}36 \\
(45.00 \%)\end{array}$ & $\begin{array}{c}22 \\
(27.50 \%)\end{array}$ & $\begin{array}{c}22 \\
(27.50 \%)\end{array}$ & 146 & 1.82 & $13^{\text {th }}$ \\
\hline 4. & Animal husbandry (Milk production) & $\begin{array}{c}17 \\
(21.25 \%)\end{array}$ & $\begin{array}{c}29 \\
(36.25 \%) \\
\end{array}$ & $\begin{array}{c}34 \\
(42.50 \%) \\
\end{array}$ & 177 & $2.21 *$ & $1^{\text {st }}$ \\
\hline 5. & Goat keeping & $\begin{array}{c}30 \\
(37.50 \%) \\
\end{array}$ & $\begin{array}{c}29 \\
(36.25 \%) \\
\end{array}$ & $\begin{array}{c}21 \\
(26.25 \%) \\
\end{array}$ & 151 & 1.89 & $11^{\text {th }}$ \\
\hline 6. & Poultry & $\begin{array}{c}18 \\
(22.50 \%)\end{array}$ & $\begin{array}{c}31 \\
(38.75 \%)\end{array}$ & $\begin{array}{c}31 \\
(38.75 \%)\end{array}$ & 173 & $2.16^{*}$ & $3^{\text {rd }}$ \\
\hline 7. & Fish farming & $\begin{array}{c}34 \\
(42.50 \%)\end{array}$ & $\begin{array}{c}23 \\
(36.25 \%)\end{array}$ & $\begin{array}{c}23 \\
(28.75 \%)\end{array}$ & 147 & 1.84 & $12^{\text {th }}$ \\
\hline 8. & Nursery raising and management & $\begin{array}{c}25 \\
(31.25 \%)\end{array}$ & $\begin{array}{c}31 \\
(38.50 \%)\end{array}$ & $\begin{array}{c}24 \\
(30.00 \%)\end{array}$ & 159 & $1.99 *$ & $9^{\text {th }}$ \\
\hline 9. & Small scale industry & $\begin{array}{c}42 \\
(52.50 \%)\end{array}$ & $\begin{array}{c}21 \\
(26.25 \%)\end{array}$ & $\begin{array}{c}17 \\
(21.25 \%)\end{array}$ & 135 & 1.69 & $14^{\text {th }}$ \\
\hline 10. & SHGs and co-operative & $\begin{array}{c}25 \\
(31.25 \%)\end{array}$ & $\begin{array}{c}25 \\
(31.25 \%)\end{array}$ & $\begin{array}{c}30 \\
(37.25 \%)\end{array}$ & 165 & $2.06^{*}$ & $4^{\text {th }}$ \\
\hline 11. & Value addition enterprise & $\begin{array}{c}31 \\
(38.50 \%)\end{array}$ & $\begin{array}{c}29 \\
(36.25 \%)\end{array}$ & $\begin{array}{c}20 \\
(25.00 \%)\end{array}$ & 129 & 1.61 & $15^{\text {th }}$ \\
\hline 12. & Village artesian & $\begin{array}{c}27 \\
(33.50 \%)\end{array}$ & $\begin{array}{c}24 \\
(30.00 \%)\end{array}$ & $\begin{array}{c}29 \\
(36.25 \%)\end{array}$ & 162 & $2.02 *$ & $8^{\text {th }}$ \\
\hline 13. & Agriculture service centre & $\begin{array}{c}27 \\
(33.50 \%)\end{array}$ & $\begin{array}{c}31 \\
(38.50 \%)\end{array}$ & $\begin{array}{c}22 \\
(27.50 \%)\end{array}$ & 155 & 1.94 & $10^{\text {th }}$ \\
\hline 14. & Business as per cost & $\begin{array}{c}17 \\
(21.25 \%) \\
\end{array}$ & $\begin{array}{c}32 \\
(40.00 \%) \\
\end{array}$ & $\begin{array}{c}31 \\
(38.50 \%) \\
\end{array}$ & 174 & $2.17 *$ & $2^{\text {nd }}$ \\
\hline 15. & Other business related to agriculture & $\begin{array}{c}24 \\
(24.00 \%)\end{array}$ & $\begin{array}{c}29 \\
(36.25 \%)\end{array}$ & $\begin{array}{c}27 \\
(33.50 \%)\end{array}$ & 163 & $2.03^{*}$ & $5^{\text {th }}$ \\
\hline \multicolumn{6}{|c|}{ Overall mean } & 1.96 & \\
\hline
\end{tabular}

\footnotetext{
* Higher than overall mean value.
} 
The data revealed in Table 1 indicated the interest of rural youth towards these agricultural allied activities and their preference level. The response of rural youth towards different agricultural activities indicated that, the 'animal husbandry (milk production)' got first rank with 2.21 mean score, followed by 'business as per cost' got second rank with 2.17 mean score, 'poultry' third rank with 2.16 mean score and the 'SHGs and co-operative' got fourth rank with 2.06 mean score, 'other business related to agriculture' got fifth rank with 2.03 mean score, 'crop production, fruit production and village artesian' $6^{\text {th }}, 7^{\text {th }}$ and $8^{\text {th }}$ rank with same mean score i.e. 2.02 and 'nursery raising and management' got ninth rank with 1.99 means score which is higher than the overall mean score 1.96. The 'agriculture service centre' got $10^{\text {th }}$ rank with 1.94 mean score, followed by 'goat keeping' with 1.89 , 'fish farming' with 1.84, 'vegetable production' with 1.82, 'small scale industry' with 1.69 and 'value addition enterprise' got $15^{\text {th }}$ rank with the lowest mean score i.e. 1.61.

Table 2: Distribution of rural youth according to their overall aspiration in different agricultural activities

\begin{tabular}{|c|c|c|}
\hline Categories & Frequency & Percentage \\
\hline Low interested & 27 & 33.75 \\
\hline Medium interested & 28 & 35.00 \\
\hline High interested & 25 & 31.25 \\
\hline Total & 80 & 100.00 \\
\hline
\end{tabular}

The data in table 2 regarding aspiration of youths in agricultural activities indicated that the majority of 35.00 per cent youths fall into Medium interested followed by 33.75 per cent youths fall into low interested and 31.25 per cent high interested category respectively. Thus, it is concluded that the majority of youths fall into medium level of aspiration in agricultural activities followed by high and low. The results are in accordance with the findings of Kudare (2012) ${ }^{[4]}$, Bhanu (2006) ${ }^{[2]}$, Shivalingaiah (1991) ${ }^{[7]}$ and Palaniswamy $(1984)^{[6]}$.

Table 3: Association between aspiration and profile of rural youth towards agricultural activities

\begin{tabular}{|c|c|c|c|}
\hline Attributes & Chi-square value & Degree of freedom & Coefficient of association \\
\hline Education & $13.60^{*}$ & 4 & 0.32 \\
\hline Caste & $10.50^{*}$ & 4 & 0.28 \\
\hline Annual income & $10.7^{*}$ & 4 & 0.29 \\
\hline Size of land holding & $14.3^{*}$ & 4 & 0.33 \\
\hline Social participation & $12.0^{*}$ & 4 & 0.30 \\
\hline Farming experience & $12.3^{*}$ & 4 & 0.30 \\
\hline Innovativeness & $12.7^{*}$ & 4 & 0.31 \\
\hline Extension participation & $9.6^{*}$ & 4 & 0.27 \\
\hline Material possession & $11.8^{*}$ & 4 & 0.30 \\
\hline Scientific orientation & $10.2^{*}$ & 4 & 0.28 \\
\hline Risk orientation & $9.8^{*}$ & 4 & 0.27 \\
\hline
\end{tabular}

*Significant at 0.05 level of probability

The perusal from Table 3 indicated that, education, caste, annual income, size of land holding, social participation, farming experience, innovativeness, extension participation, material possession, scientific orientation and risk orientation had significantly associated with the aspiration level of rural youth towards different agricultural activities at 0.05 level of probability with 4 degree of freedom. The higher education of the rural youth change his view towards agriculture they know that farming is an successful business when we utilize new techniques, equipments, seeds and fertilizers all this knowledge is consumed by the rural youth due to education. These findings are partially supported with the findings of Pakhmode et al. (2018) ${ }^{[5]}$ and Chachere et al. (2018) ${ }^{[3]}$.

\section{Reference}

1. Appadurai A. The capacity to aspire: culture and the terms of recognition". Culture and Public Action, Stanford University

Press, http://www.cultureandpublicaction.org, 2004.

2. Bhanu VL. Study on aspirations of rural youth and their attitude towards rural development activities in dharwad district of karnataka state M.Sc. (Agri.) Thesis, University of Agricultural Sciences, Dharwad, 2006.

3. Chachere GS, Gohad VV, Bhoyar RM and Bhagat KK. Attitude of rural youth towards farming as a major occupation. International Journal of Chemical Studies. 2018; 6(4):2789-2791.
4. Kudare S. A study on occupational aspiration of rural youth in relation to agricultural and allied sectors in Dhar district M.P. M.Sc (Agri) Thesis, Rajmata Vijayaraje Scindia Krishi Vishwa Vidyalaya, Gwalior, 2012.

5. Pakhmode PS, Rathod MK, Bhagat MC. Attitude of rural youth towards farming as a major occupation. International Journal of Chemical Studies. 2018; 6(1):1735-1738.

6. Palaniswamy A. A study on modernization characteristics and training needs of sugarcane growers. Ph.D. Thesis, University of Agricultural Sciences, Bangalore, 1984.

7. Shivalingaiah YN. Participation of rural youth in agriculture - their problems and training needs. M.Sc. (Agri.) Thesis, University of Agricultural Sciences, Bangalore, 1991. 